\title{
紫外域日射に関する許容被照時間数の地域特性解析 \\ ESTIMATION OF REGIONAL CHARACTERISTICS ON THE PERMISSIBLE EXPOSURE DURATION FOR EXPOSURE TO ULTRAVIOLET SOLAR RADIATION
}

\author{
垂 水弘夫*, 新 聖子** \\ Hiroo TARUMI and Masako SHIN
}

The CFC utilized as a refrigerant of air conditioner causes the ozone layer depletion. Today, the ozone depletion in the stratosphere is recognized as a major environmental problem, because which results in a significant increase in solar ultraviolet (UV) radiation that reaches the surface of the Earth. Increase of the UV radiation will have an influence on the human health. The purpose of this study is to present analyzed results of the permissible exposure duration for exposure to the solar UV radiation at Sapporo, Kanazawa, Tsukuba, Kagoshima and Naha, and to discuss the regional characteristics from the viewpoint of the UV radiation exposure.

Through analysis of the permissible exposure duration, the followings were shown: (1) The level of the permissible exposure duration in every month at 5 observation points. (2) The relation between the permissible exposure duration and the global solar radiation. (3) The permissible exposure duration according to the class of simplified weather classification based on the cloud amount in each region and in each month.

Keywords : Ultraviolet solar radiation, Permissible exposure duration, Simplified weather classification 紫外域日射, 許容被照時間数, 簡易天気分類

1.はじめに

空気調和設備などの熱媒として広範に使用されてきたフロンが， 今日ではオゾン層破壊物質として認知され，破壊の進行に伴う地上 到達紫外域日射量の増大が懸念されている。

紫外域日射防御対策を個人のレベルで考える時, 必要とされるの は天気と被曝する可能性のある紫外域日射量との関係を知ることで あろう。筆者らはこれまでに, Brewer 観測機注1が設置されているわ が国の 5 観測点（札幌，金沢，つくば，鹿児島および那羁）の紫外 域日射分光観測データを用いて, 日積算レベルの生体影響紫外線 DUV（Damaging Ultraviolet Radiation）を求め, 地域や季節の特性解 析をはじめとして, 全量值である UV-B との傾向の相違や, 日射量 との対応関係の検討，また，昼間雲量に基づく簡易天気分類別の DUV 值の提示などを行ってきた。1)2)

本研究では, 地上到達紫外域日射のエネルギ一量の大小関係を, 許容被照時間数注 2 の長短関係に置き換えることによって，地域住民 にとって有用な公衆衛生学上の紫外域日射関係資料を作成・整備す ることを目的に，一連の解析を行ったので報告する。具体的には WHO（世界保健機関）が公表している基準許容被曝量 $30 \mathrm{~J} / \mathrm{m}^{2}$ を用
い, 時刻別の DUV 值 $\left(\mathrm{W} / \mathrm{m}^{2}\right)$ で除すことにより, 許容被照時間数 （s）を求める。 ${ }^{3}$ 注 3 また, このようにして得られた許容被照時間

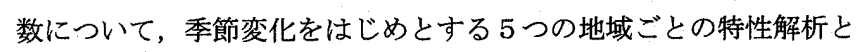
地域間比較を行うとともに, 簡易天気分類に基づく許容被照時間数 を提示するものである。

既往の研究に関しては, 既報1）2）の中で整理しているが，本研究 で評価指標としている許容被照時間数について，過去数年分の蓄積 した分光観測データをもとにこれを算定し，地域特性等を解析した 研究例は見当たらない。

\section{2. 許容被照時間数の算定方法と解析対象データ}

毎日の紫外域日射の許容被照時閒数を求めるにあたっては, 図 1 および次式に示すように 1 日の中で最大の DUV 值をとる正時の データから降順に秒積算し, 積算値((2)式左辺)が $30\left(\mathrm{~J} / \mathrm{m}^{2}\right)$ 以下と なる最大の秒数として算定する。

$$
\begin{gathered}
\mathrm{t}=30\left(\mathrm{~J} / \mathrm{m}^{2}\right) / \operatorname{DUV}\left(\mathrm{W} / \mathrm{m}^{2}\right) \\
\Sigma\left\{\operatorname{DUV}\left(\mathrm{W} / \mathrm{m}^{2}\right) \times \Delta \mathrm{T}\right\} \leqq 30\left(\mathrm{~J} / \mathrm{m}^{2}\right)
\end{gathered}
$$

ここに, $\mathrm{t}$ : 許容被照時閒数 $(\mathrm{sec}), \quad \Delta \mathrm{T}: 1(\mathrm{sec})$
$*$ 金沢工業大学居住環境学科 教授.工博

** 金沢工業大学大学院建築学専攻 大学院生
Prof., Dept. of Environmental Design, Kanazawa Institute of Technology, Dr. Eng. Graduate Student, Dept. of Architecture, Kanazawa Institute of Technology 


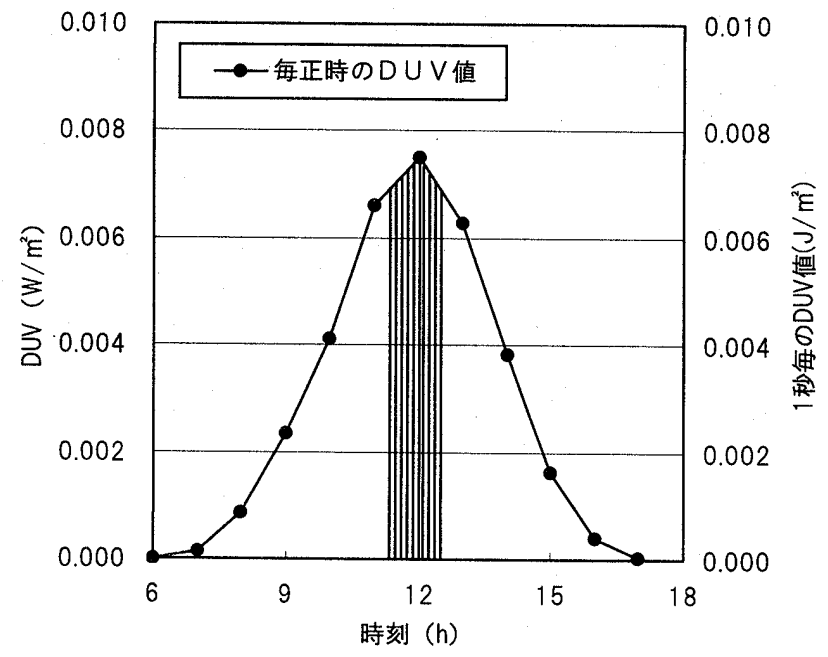

図 1 DUV 之許容被照時間の関係

1998 年 2 月 24 日札幌，許容被昭時間: 4169 秒

※ 縦線の本数(1 秒毎の DUV 值)が許容被照時間数となる

なお，札幌など北に位置する地域では冬季に 1 日の積算值が基準 值 $30 \mathrm{~J} / \mathrm{m}^{2}$ に満たない場合が生ずるが，これらを解析対象から除くと， 該当月の平均值が実態よりも大幅に小さく表現されてしまう怖れが あるため，そのような場合は日の出から日の入までの可照時間数 （秒）を許容被照時間数データとして採用している。表 1 に解析対 象有効デー夕数（日数）、を観測地点別にまとめた。観測機の設置時 期が早く，9年間の蓄積データを使用したつくばのデータ数が 2994 日と最も多く，これに 8 年間の蓄積データの札幌 $(2818$ 日)，鹿児 島 $(2735$ 日), 那霸 $(2705$ 日) と続いている。3 年間の蓄積デー夕 を使用する金沢の有効日数は 857 日である。

\section{3. 紫外域日射に関する許容被照時間数と関連データの基本統計}

5 地域の DUV 全有効データについて許容被照時間数を算定し, 基 本統計データを表 2 に整理した。月別の平均値，標準偏差（SD）， 最大值, 最小值, サンプル数（N）を示し, 年間を通じた平均許容 被照時間数もまとめている。また，関連データとして日積算 DUV と日全天日射量を取り上げ，同一のデータ有効日に関する平均值を 示している。図 2 には，許容被照時間数の年間の変化を，標準偏差 を含めて提示した。

まず，札幌，金沢，つくば，鹿児島および那覇の 5 地域の年間平 均許容被照時間数をみると, 夫々, 6518 秒 (1 時間 48 分 38 秒), 3566 秒 (59 分 26 秒), 3148 秒 (52 分 28 秒), 2034 秒 (33 分 54 秒), 1271 秒 (21 分 11 秒) となっている。最も北に位置する札幌と最も南に 位置する那羁との差は, 紫外域日射の許容被照時間数でみて 1 時間 27 分 27 秒である。両地域閒の比をとるとおよそ 5.1 となり，大きな 相違が認められる。つくばを基準（1.0）として各地域の許容被照時 間数をみると, 札幌が約 2.1 倍, 金沢が約 1.1 倍, 鹿児島が約 0.6 倍, 那覇が約 0.4 倍に相当することが判る。

次に，地域ごとの月別許容被照時間数の傾向を見ていく。札幌で は, 許容被照時間数の月別平均が最も小さいのは 7 月で 1160 秒 (19 分 20 秒), 最も大きいのは 12 月で 21438 秒 (5 時間 57 分 18 秒) で あり, 両者間の比は約 18.5 となっている。また, 許容被照時間数に
表 1 解析対象地域と対象データー筧

\begin{tabular}{|c|c|c|c|c|}
\hline 地域 & 緯度 & 経度 & 対象 $\vec{\tau}-タ$ & 観測日数 \\
\hline 柇幌 & $43^{\circ} 03^{\prime} \mathrm{N}$ & $141^{\circ} 20^{\prime}$ & $1991.01 \sim 1998.12$ & 2818 \\
\hline 金沢 & $36^{\circ} 31^{\prime} \mathrm{N}$ & $136^{\circ} 37^{\prime}$ & $1997.03 \sim 2000.09$ & 857 \\
\hline つくば & $36^{\circ} 03^{\prime} \mathrm{N}$ & $140^{\circ} 08^{\prime}$ & $1990.01 \sim 1998.12$ & 2994 \\
\hline 鹿児島 & $31^{\circ} 33^{\prime} \mathrm{N}$ & $130^{\circ} 33^{\prime}$ & $1991.01 \sim 1998.12$ & 2735 \\
\hline 那覇 & $26^{\circ} 12^{\prime} \mathrm{N}$ & $127^{\circ} 41^{\prime}$ & $1991.01 \sim 1998.12$ & 2705 \\
\hline
\end{tabular}

表 2 全蓄積データを用いた紫外域日射及び許容被照時間数に関する 基本統計値

\begin{tabular}{|c|c|c|c|c|c|c|c|c|}
\hline \multirow{2}{*}{ 地域 } & \multirow{2}{*}{ 月 } & \multicolumn{4}{|c|}{ 許容被照時間数（秒） } & \multirow{2}{*}{$\begin{array}{l}\text { 日糦算 } \\
\text { DUV }{ }^{* 1}\end{array}$} & \multirow{2}{*}{$\begin{array}{l}\text { 日全天 } \\
\text { 日射 }{ }^{* 2}\end{array}$} & \multirow{2}{*}{$\begin{array}{c}\text { 観測日数 } \\
\text { (日) }\end{array}$} \\
\hline & & 平均 & SD & 最大 & 䏇小 & & & \\
\hline \multirow{13}{*}{ 札幌 } & 1月 & 17811 & 10085 & 36334 & 4772 & 0.0413 & 5.91 & 243 \\
\hline & 2月 & 8762 & 7791 & 39510 & 2247 & 0.0814 & 8.72 & 215 \\
\hline & 3月 & 3626 & 2000 & 15848 & 1302 & 0.1693 & 12.66 & 233 \\
\hline & 4月 & 2532 & 2275 & 20689 & 828 & 0.2839 & 15.72 & 235 \\
\hline & 5月 & 1862 & 1940 & 21628 & 617 & 0.4261 & 17.42 & 242 \\
\hline & 6月 & 1402 & 1057 & 7429 & 530 & 0.5395 & 17.82 & 232 \\
\hline & 7月 & 1160 & 735 & 5521 & 543 & 0.5932 & 16.70 & 242 \\
\hline & 8月 & 1323 & 1145 & 10054 & 526 & 0.5352 & 14.81 & 241 \\
\hline & 9月 & 1921 & 2035 & 24648 & 769 & 0.3511 & 12.74 & 221 \\
\hline & 10月 & 3985 & 3070 & 20531 & 1223 & 0.1659 & 9.37 & 243 \\
\hline & 11月 & 12217 & 9515 & 35955 & 2909 & 0.0619 & 5.87 & 233 \\
\hline & 12月 & 21438 & 9319 & 34286 & 7768 & 0.0333 & 4.71 & 238 \\
\hline & 年間 & 6518 & 8745 & - & - & 0.2749 & 11.89 & 2818 \\
\hline \multirow{13}{*}{ 金沢 } & 1月 & 9955 & 9187 & 36507 & 2598 & 0.0731 & 4.79 & 52 \\
\hline & 2月 & 7715 & 10031 & 39061 & 1560 & 0.1389 & 7.30 & 26 \\
\hline & 3月 & 2868 & 4263 & 26602 & 883 & 0.3018 & 12.69 & 70 \\
\hline & 4 月 & 2173 & 1896 & 8709 & 730 & 0.3819 & 14.57 & 79 \\
\hline & 5月 & 1220 & 950 & 7000 & 561 & 0.5734 & 18.05 & 67 \\
\hline & 6月 & 1395 & 1057 & 5647 & 491 & 0.5695 & 15.36 & 91 \\
\hline & 7月 & 1157 & 897 & 4748 & 505 & 0.6366 & 15.03 & 89 \\
\hline & 8月 & 1051 & 1233 & 11491 & 469 & 0.6325 & 13.69 & 80 \\
\hline & 9 月 & 1550 & 1202 & 8920 & 644 & 0.4095 & 12.24 & 89 \\
\hline & 10 月 & 2669 & 4410 & 39581 & 770 & 0.2680 & 10.12 & 82 \\
\hline & 11月 & 6112 & 8389 & 37434 & 1789 & 0.1358 & 7.16 & 70 \\
\hline & 12月 & 9141 & 8391 & 35789 & 3122 & 0.0788 & 4.98 & 62 \\
\hline & 年間 & 3566 & 5605 & - & - & 0.3839 & 11.80 & 857 \\
\hline \multirow{13}{*}{ つくば } & 1月 & 6995 & 7246 & 37818 & 2385 & 0.1013 & 8.54 & 249 \\
\hline & 2月 & 4100 & 4104 & 40435 & 1656 & 0.1557 & 11.22 & 201 \\
\hline & 3月 & 3178 & 4244 & 41976 & 992 & 0.2477 & 12.13 & 251 \\
\hline & 4月 & 1935 & 1684 & 11359 & 759 & 0.3759 & 14.76 & 252 \\
\hline & 5月 & 1572 & 1471 & 10091 & 647 & 0.4791 & 15.92 & 254 \\
\hline & 6月 & 1441 & 988 & 5994 & 530 & 0.4859 & 13.03 & 250 \\
\hline & 7月 & 1218 & 782 & 4514 & 469 & 0.5778 & 14.44 & 255 \\
\hline & 8月 & 1084 & 944 & 11188 & 467 & 0.6091 & 14.54 & 260 \\
\hline & 9 月 & 1797 & 1830 & 14924 & 608 & 0.4039 & 10.89 & 247 \\
\hline & 10月 & 2462 & 1923. & 20023 & 949 & 0.2517 & 9.26 & 266 \\
\hline & 11月 & 5055 & 5841 & 37037 & 1591 & 0.1428 & 8.07 & 258 \\
\hline & 12月 & 7247 & 7235 & 35956 & 2801 & 0.0930 & 7.53 & 251 \\
\hline & 年間 & 3148 & 4471 & - & - & 0.3304 & 11.70 & 2994 \\
\hline \multirow{13}{*}{ 鹿児島 } & 1月 & 4063 & 5417 & 37800 & 1445 & 0.1677 & 9.15 & 237 \\
\hline & 2月 & 2553 & 2470 & 24628 & 956 & 0.2506 & 11.62 & 215 \\
\hline & 3月 & 2556 & 3876 & 43781 & 698 & 0.3378 & 12.60 & 234 \\
\hline & 4月 & 1635 & 1838 & 13348 & 539 & 0.4897 & 15.84 & 231 \\
\hline & 5月 & 1187 & 1099 & 12138 & 498 & 0.5940 & 17.53 & 236 \\
\hline & 6月 & 1472 & 1536 & 15064 & 368 & 0.5733 & 14.44 & 220 \\
\hline & 7月 & 1010 & 1295 & 10850 & 396 & 0.7911 & 17.76 & 222 \\
\hline & 8月 & 749 & 563 & 5881 & 391 & 0.8270 & 18.89 & 225 \\
\hline & 9月 & 1112 & 957 & 8511 & 479 & 0.5797 & 16.20 & 213 \\
\hline & 10月 & 1552 & 1234 & 15015 & 766 & 0.3855 & 13.37 & 225 \\
\hline & 11月 & 2518 & 2099 & 19426 & 973 & 0.2364 & 10.63 & 235 \\
\hline & 12月 & 3719 & 3507 & 36640 & 1832 & 0.1615 & 8.81 & 242 \\
\hline & 年間 & 2034 & 2787 & - & - & 0.4456 & 13.85 & 2735 \\
\hline \multirow{13}{*}{ 那羁 } & 1月 & 2135 & 1351 & 10662 & 912 & 0.2558 & 8.84 & 237 \\
\hline & 2月 & 1955 & 1778 & 11528 & 678 & 0.3248 & 9.89 & 201 \\
\hline & 3月 & 1529 & 1541 & 14631 & 543 & 0.4555 & 11.98 & 225 \\
\hline & 4月 & 1068 & 688 & 4420 & 438 & 0.5822 & 14.16 & 231 \\
\hline & 5月 & 990 & 758 & 6351 & 412 & 0.6935 & 16.10 & 238 \\
\hline & 6月 & 810 & 702 & 7029 & 397 & 0.8476 & 17.73 & 225 \\
\hline & 7月 & 592 & 310 & 3305 & 395 & 1.0002 & 20.25 & 223 \\
\hline & 8月 & 606 & 421 & 5793 & 345 & 0.9592 & 19.43 & 231 \\
\hline & 9月 & 738 & 405 & 4088 & 395 & 0.7597 & 16.99 & 216 \\
\hline & 10月 & 1120 & 600 & 5646 & 592 & 0.4846 & 13.23 & 216 \\
\hline & 11月 & 1472 & 800 & 5220 & 497 & 0.3316 & 10.77 & 223 \\
\hline & 12月 & 2208 & 1682 & 14637 & 1116 & 0.2577 & 9.29 & 239 \\
\hline & 年間 & 1271 & 1184 & - & - & 0.5795 & 14.06 & 2705 \\
\hline
\end{tabular}

$\mathrm{SD}$ :標準偏差 $※ 1:$ 単位 $\left(\mathrm{kJ} / \mathrm{m}^{2}\right.$.日) $※ 2$ :単位 $\left(\mathrm{MJ} / \mathrm{m}^{2} \cdot\right.$ 日) 


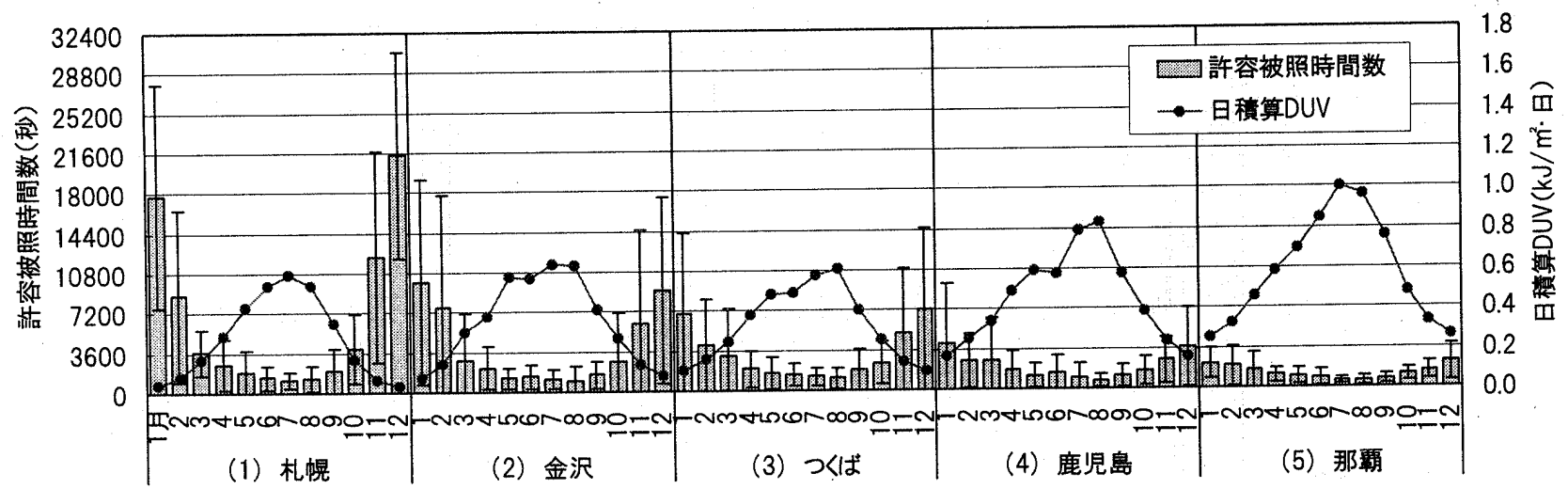

図 2 地域別許容被照時間数の月平均値 （維の細実線は標準偋差を表す）

ついては, 晴天日に得られる最小の時間数が問題となるが，月別に みると観測日として最小の許容被照時間数が記録されたのは 8 月の 526 秒 (8 分 46 秒) であり, これに 6 月の 530 秒 (8 分 50 秒), 7 月の 543 秒（9 分 3 秒）が続いている。

金沢において許容被照時間数の平均値が最も小さい月は 8 月であ り, その値は 1051 秒 (17 分 31 秒) となっている。一方, 平均値が 最も大きいのは 1 月の 9955 秒（2 時間 45 分 55 秒）であり，8 月と 比べた場合の比はおよそ 9.5 となって，この季節間の開きは札幌の 半分程度に縮小していることが判る。金沢で最小の許容被照時間数 が観測されたのは 8 月で，469 秒（7 分 49 秒）となっている。

つくばでは, 許容被照時間数の月別平均が最も小さいのは 8 月の 1084 秒 (18 分 4 秒), 最も大きいのは 12 月の 7247 秒 (2 時間 47 秒) であり，両者間の比は約 6.7 となっている。季節間の開きは札幌, 金沢，つくばと南の地域になるに連れて縮小傾向にあるが，8月の 月平均値を取り上げてみると，つくばよりも金沢の方が小さくなる という緯度上の並びに反する数值が示されている。2 $8^{\prime}$ の緯度差以 上に，天候や大気の透過率等の状態が卓越した結果と考えられる。 つくばにおける最小の許容被照時間数は，8 月に観測された 467 秒 （7 分 47 秒）であり，これは金沢とほぼ同様の值である。

鹿児島では, 許容被照時間数の月別平均値が最も小さいのは 8 月 であり, 749 秒 (12 分 29 秒) となっている。一方, 平均值が最も大 きい月は 1 月で 4063 秒（1 時間 7 分 43 秒）であり，両者間の比は およそ 5.4 となって，つくば以上に季節間の開きが縮小している。 また, 最小の許容被照時間数が観測されたのは 6 月で, 368 秒 $(6$ 分 8 秒）となっている。

那羁では, 許容被照時間数の月別平均が最も小さいのは 7 月の 592 秒 (9 分 52 秒)，最も大きいのは 12 月の 2208 秒 (36 分 48 秒) であ り，両者間の比は約 3.7 となっている。季節間の開きは 5 地域を通 じて最も小さい。また，最小の許容被照時間数は 8 月に観測された 345 秒 (5 分 45 秒) であり, これも 5 地域の中で最も小さい值であ る。

過去に観測された最小の許容被照時間数について，札幌と那覇の 比をとると 1.5 になる。また, つくばを基準（1.0）としてみると， 札幌が約 1.1 倍, 金沢が約 1.0 倍, 鹿児島が約 0.8 倍, 那霸が約 0.7 倍に相当している。これを冒頭に示した年間平均の許容被照時間数 の地域差の結果と比較すると，最小の許容被照時間数でみる地域差 が顕著に縮小していることは明白である。紫外域日射被曝に関して

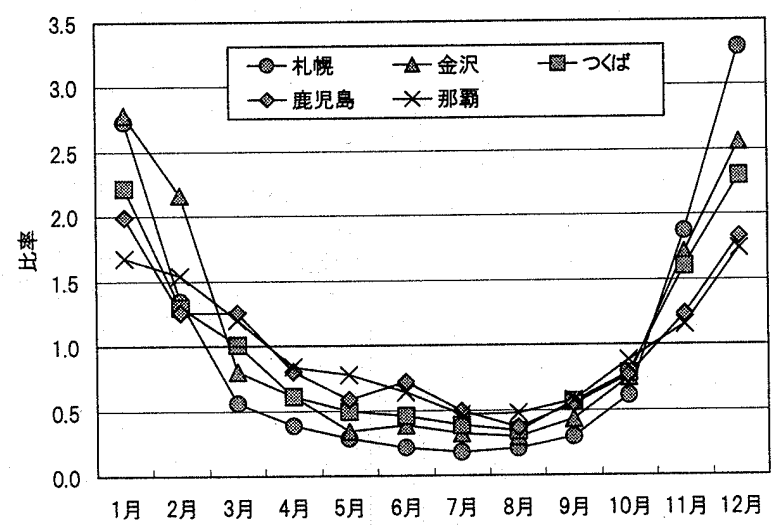

図 3 許容被照時間月平均値の年平均値に対する比率

特に配慮が求められる 6 月から 8 月にかけては，年間平均値でみる よりもはるかに南北の地域差が小さくなっている点に留意する必要 があろう。

図 2 からも，北に位置する札幌や金沢の年間平均許容被照時間数 を押し上げているのは，冬季の期間における時間数の長さであるこ とが判る。また, 図 2 中に併記した月平均の日積算 DUV をみると, 札幌, 金沢およびつくばの最大值が, 何れもほぼ同じ $0.6 \mathrm{~kJ} / \mathrm{m}^{2} \cdot$ 日程 度に達しており，夏季においてこれら 3 地点閒で緯度による許容被 照時間数の相違が余り認められない証左となっている。

次に, 各地域における許容被照時間数の季節変化の傾向を把握す るために, 年平均值で各月の平均值を除して比率を求め, 図 3 を作 成した。緯度の低い那覇や鹿児島では年間の季節変化が小さく, 札 幌，金沢などの高緯度地域ほど許容被照時間数の夏季と冬季の差が 大きい。 5 地域ともに 11 月〜2 月までは各月平均值が年平均值を上 回り, 4 月〜 10 月までの間は各月平均値が年平均值を下回っている。 地域によって様子が異なるのは 3 月である。すなわち,つくばでは 年平均值と月平均值がほぼ同じレベルにあり，鹿児島と那覇では月 平均值が年平均値を上回り, 金沢と札幌では月平均值が年平均值を 下回っている。この結果, 金沢と札幌では 1,2 月から 3 月にかけて 急速に許容被照時間数が短くなる様子が示されており, 冬型の気圧 配置の解消に伴ってつくば以南の地域よりも紫外域日射対策に関す る住民の意識を喚起する必要があると思われる。表 2 から金沢と鹿 児島の 3 月の許容被照時間数を読むと, 夫々, 2868 秒 (47 分 48 秒), 

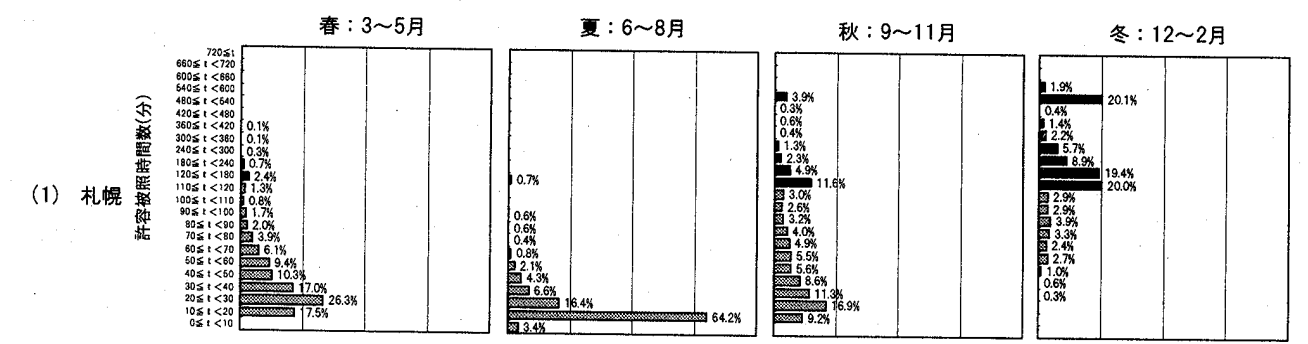

(2) 金沢
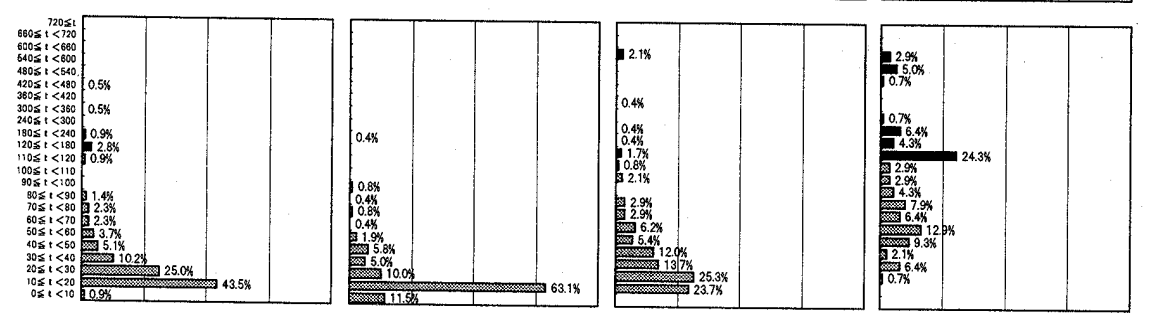

(3) つくば
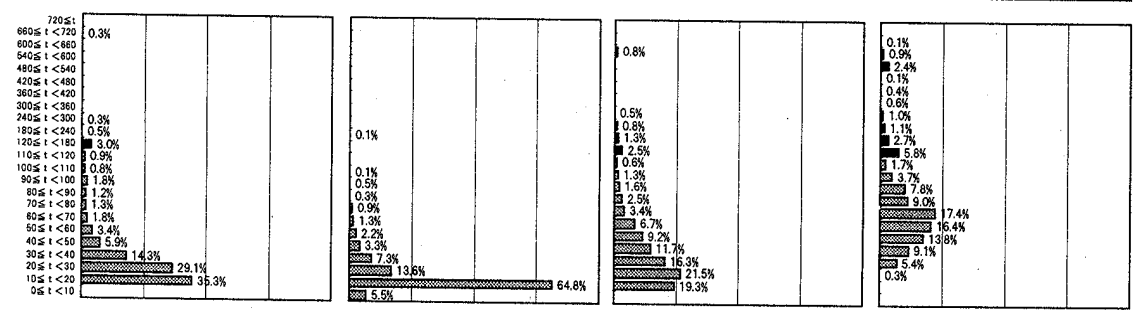

（4）鹿児島
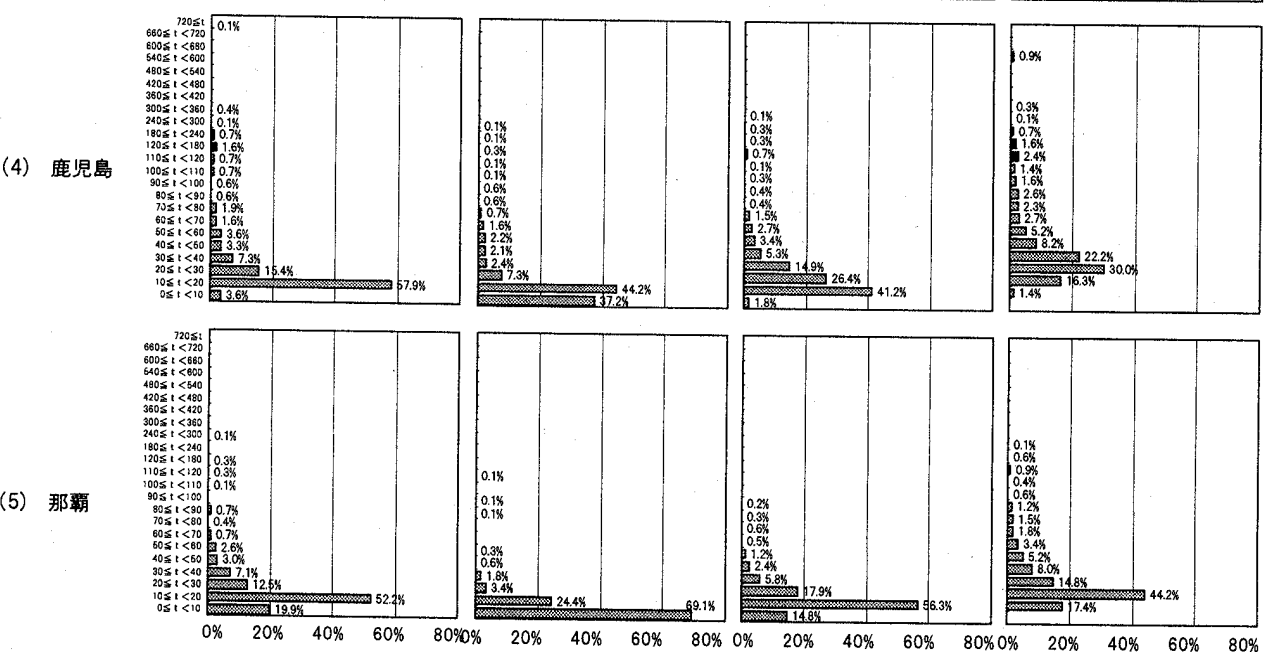

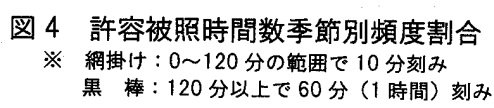

2556 秒（42 分 36 秒）孔なっており, やはり鹿児島の方が短いもの の，かなり接近した数值となっていることが判る。

許容被照時間数に関する各地域, 各季節の出現頻度割合の分布を 図 4 に提示した。緯度が低くなるに連れて, 短い許容被照時間数亏 ンクの出現割合が高くなるという全体的な傾向がみられる。また, 6 〜8 月には，20 分以内の許容被照時間数の日が，札幌で $67 \%$, 金沢

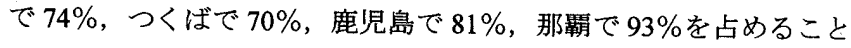
が示されている。許容被照時間数が数時間以上に及ぶ日が多いのは, 冬季の札幌と金沢が中心であり，これ以外の地域や季節ではほとん どの場合，被照時間に注意する必要があると云えよう。

本研究で求めた紫外域日射に関する許容被照時間数について，日 全天日射量とのクライモグラフを作成し，図 5 に提示した。グラフ 上の移動範囲が広い札幌については, 月平均値の位置に月の数字を
表示している。

5 地点全体の分布範囲を夫々の最小值, 最大值でみると, 日全天 日射量が $4.71 \mathrm{MJ} / \mathrm{m}^{2}$ ・日（札幌，12 月） $20.25 \mathrm{MJ} / \mathrm{m}^{2}$ ・日（那革, 7 月）であるときに, 許容被照時間数は 592 秒 (那龩, 7 月) 〜 21438 秒（札幌，12月）となっている。最小值と最大値の比をとると, 日 全天日射量が 4.3 倍の範囲で分布しているのに対し, 許容被照時間 数の方は 36.2 倍の範囲に分布していることになる。これは, 日全天 日射量は 1 日の積算値として定まるが, 一方の許容被照時間数は, 多くが正午前後の数分から数十分で定められることに起因している ものと推測される。さらに, 一地域についてみても, 札幌の 1 月と 11 月，また，2月と 10 月などはほぼ同レベルの日射量であるにも関 わらず，許容被照時間数には大きな差異が認められる。日射量自体 は比較的測定が容易で，人体としても量的な大小を体感できるもの 
ではあるが，必ずしも紫外域日射に関する許容被照時間数とは $1: 1$ に対応するものではないことを認識しておく必要があろう。

\section{4. 簡易天気分類による許容被照時間数}

天気による許容被照時間数の相違を把握することは，各地域の住

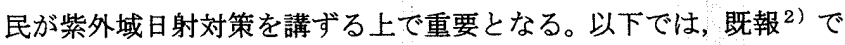
日積算 DUVについて実施したのと同様の簡易天気分類の手法注4 用いて, 許容被照時間数の整理を試みた。「快晴」,「晴」および「最」 の簡易天気分類に従い，5地域の月別平均値と出現割合を表 3 に示 す。

まず，各地域の天気の月別出現割合をみると，全体として「最」 や「晴」の日が多く,「快晴」は数\%から十数\%程度に留まる傾向に ある。ただし，つくばにおいては 11 月から 2 月にかけて「快晴」の 割合が 25〜35\%と，他の天気に近い出現割合となっている。

次に, 簡易天気分類による許容被照時間数の月別平均値を各地域 の月ごとに見比べると，多くの場合「最」，「晴」，「快晴」の順に数 值が小さくなる傾向が示されている。例えば, つくばで「快晴」の 許容被照時間数が最も短い7 月についてみると,「最」の 1506 秒 $(25$ 分 6 秒）に対して，「晴」は 804 秒（13 分 24 秒)，「快晴」は 717 秒 （11 分 57 秒）といった具合である。また，「快晴」の許容被照時間 数が最も長い 12 月についてみても，「曇」の 14491 秒（4 時間 1 分 31 秒）に対して，「晴」が 5263 秒（1 時間 27 分 43 秒)，「快晴」が 4607 秒（1 時間 16 分 47 秒）などとなっている。ただ，表中で網掛 けを施した地域と月では,「快晴」よりも「晴」の許容被照時間数の 方が僅かながら短くな゙るという現象が見られる。「快晴」のサンプル 数自体が少ないことによるものか，雲の存在に起因する紫外域日射 の天空散乱成分の増大によるものかは，ここでは明確でないが，そ うした事実が，金沢，鹿児島および那覇の春から夏にかけて存在す ることを指摘しておきたい。

各地域ごとに, 許容被照時間数が最も短い月と天気分類，さらに 秒数を挙げれば，札幌では 7 月の「快晴」で 793 秒（13 分 13 秒)， 金沢では 8 月の「晴」で 692 秒 (11 分 32 秒)，つくばでは 7月の「快 晴」で 717 秒 (11 分 57 秒)，鹿児島では 7 月の「快晴」で 531 秒 (8 分 51 秒), 那霸では 7 月の「晴」で 529 秒（8 分 49 秒）となってい る。

紫外域日射への被曝に関しては，やはりその短さが問題となるた め, 3600 秒（1 時間）までの範冊で，簡易天気分類に基づく許容被 照時間数をグラフ化し，図 6 に提示した。「睤」と他の「晴」「快晴」 との差異は明確であること，「晴」と「快晴」との差は夏季を中心と する時期にははっきりとせず，冬季の前後に明瞭となること，など が読み取れる。

\section{5.まとめ}

本論文は，紫外域日射に関する許容被照時間数を算定し，地域に よる特性を明らかにすることを目的として，気象庁ならびに金沢工 業大学が蓄積している紫外域日射分光観測デー夕等の解析を行った ものである。研究成果を以下にまとめる。

（1）札幌, 金沢, つくば, 鹿児島および那羁の 5 地域について, こ れまでの全蓄積データに基づく許容被照時間数を月別平均值として 整理し，過去に観測された最小の時間数を含めて提示した。

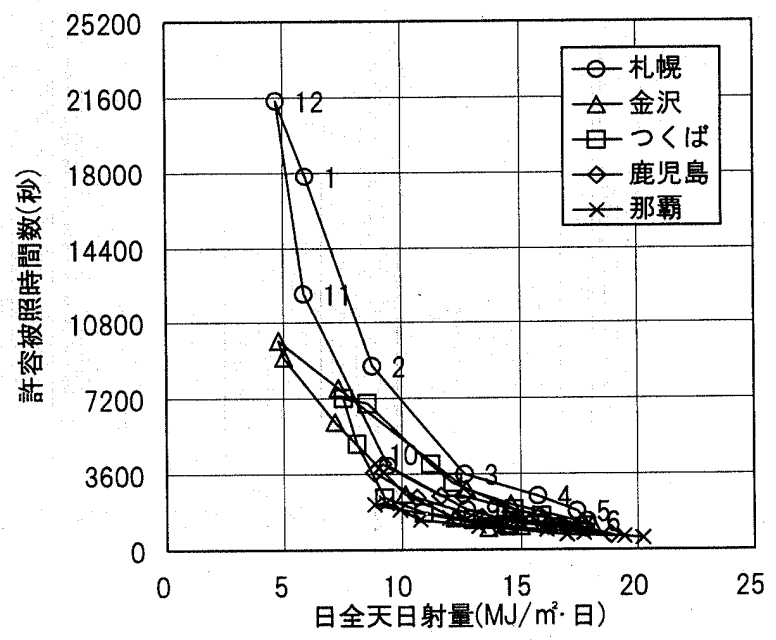

図 5 許容被照時間数と日全天日射量 月平均値によるクライモグラフ

表 3 簡易天気分類毎の月平均許容被照時間数

\begin{tabular}{|c|c|c|c|c|c|c|c|}
\hline & 快日 & & 晴 & & & \\
\hline & & 平均(秒) & 突気割合 & 平均 $($ 秒) & 天哥割合 & 平场(秒) & 天気割合 \\
\hline \multirow{11}{*}{ 札幌 } & 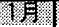 & 12296 & צ' & 12160 & $450 \%$ & & $54 \%$ \\
\hline & 2月 & 4658 & $6 \%$ & 5963 & $40 \%$ & 11343 & $53 \%$ \\
\hline & 3月 & 2287 & $6 \%$ & 2888 & $41 \%$ & 4371 & $52 \%$ \\
\hline & $\begin{array}{l}4 \text { 月 } \\
5 \text { 月 }\end{array}$ & $\begin{array}{l}1574 \\
1068\end{array}$ & $\begin{array}{l}11 \% \\
12 \%\end{array}$ & $\begin{array}{l}1695 \\
1106\end{array}$ & $\begin{array}{l}39 \% \\
30 \%\end{array}$ & $\begin{array}{l}3373 \\
2402\end{array}$ & $\begin{array}{l}51 \% \\
59 \%\end{array}$ \\
\hline & 6月 & 808 & $10 \%$ & 867 & $33 \%$ & 1817 & $57 \%$ \\
\hline & 7月 & 793 & 58 & 795 & $34 \%$ & 1396 & $61 \%$ \\
\hline & 8月 & 816 & $6 \%$ & 893 & $35 \%$ & 1626 & $59 \%$ \\
\hline & 9月 & 1243 & $6 \%$ & 1303 & $44 \%$ & 2552 & $50 \%$ \\
\hline & 10月 & 2449 & $9 \%$ & 3055 & $48 \%$ & 5328 & $43 \%$ \\
\hline & 11月 & 5015 & $3 \%$ & 8485 & 45\% & 16026 & $51 \%$ \\
\hline & 12月 & 13265 & $1 \%$ & 16414 & $43 \%$ & 25544 & $55 \%$ \\
\hline \multirow{12}{*}{ 金沢 } & 1F & 3803 & $2 \%$ & 7380 & $24 \%$ & 11053 & $75 \%$ \\
\hline & 2月 & 2106 & $17 \%$ & 2466 & $25 \%$ & 11885 & $58 \%$ \\
\hline & 3月 & 1408 & $13 \%$ & 1609 & $46 \%$ & 4817 & $41 \%$ \\
\hline & 4月 & 1263 & $16 \%$ & 1451 & $30 \%$ & 2867 & $53 \%$ \\
\hline & 5月 & 883 & 124 & 830 & 80\% & 1610 & $49 x$ \\
\hline & 6月 & 741 & $7 \%$ & 808 & $31 \%$ & 1737 & $63 \%$ \\
\hline & $7 \%$ & 812 & 34) & 709 & $25 \%$ & 1376 & 719 \\
\hline & 8 月 & 748 & 84 & 692 & 374 & 1459 & 554 \\
\hline & 9 月 & 930 & $10 \%$ & 952 & $28 \%$ & 1615 & $62 \%$ \\
\hline & 10月 & 1495 & 168 & 1699 & 438 & 4117 & $41 \%$ \\
\hline & 11月 & 2477 & $14 \%$ & 3135 & $29 \%$ & 8509 & $57 \%$ \\
\hline & 12月 & 3982 & $5 \%$ & 4620 & $35 \%$ & 12247. & $60 \%$ \\
\hline \multirow{12}{*}{ つくば } & T月 & 4119 & $35 \%$ & 4879 & $38 \%$ & 13875 & 278 \\
\hline & 2月 & 2811 & $30 \%$ & 3235 & $39 \%$ & 6399 & $31 \%$ \\
\hline & 3 月 & 1747 & $16 \%$ & 1816 & $39 \%$ & 4839 & $45 \%$ \\
\hline & 4月 & 1185 & $18 \%$ & 1269 & $37 \%$ & 2775 & $45 \%$ \\
\hline & 5月 & 964 & $10 \%$ & 971 & $34 \%$ & 2056 & $56 \%$ \\
\hline & 6月 & 852 & $3 \%$ & 882 & $26 \%$ & 1673 & $71 \%$ \\
\hline & 7月 & 717 & $7 \%$ & 804 & $33 \%$ & 1506 & $60 \%$ \\
\hline & 8月 & 734 & $4 \%$ & 789 & $46 \%$ & 1388 & $50 \%$ \\
\hline & $6 \%$ & 1015 & 38) & 984 & $38 \%$ & 2868 & 69.6. \\
\hline & 10月 & 1618 & $12 x$ & 1692 & $39 \%$ & 3286 & 498 \\
\hline & 11月 & 2856 & $25 \%$ & 3199 & 38\% & 8530 & $36 \%$ \\
\hline & 12月 & 4607 & $34 \%$ & 5263 & $42 \%$ & 14491 & $24 \%$ \\
\hline \multirow{12}{*}{ 鹿児荀 } & 1月 & 2299 & $14 \%$ & 2491 & $46 \%$ & 6438 & $41 \%$ \\
\hline & 29 & 1494 & 148 & 1741 & 44\% & 3740 & $42 x$ \\
\hline & 3 月 & 1096 & 148 & 1125 & $32 \%$ & 3791 & 548 \\
\hline & 4月 & 783 & $12 \%$ & 918 & $39 \%$ & 2415 & $49 \%$ \\
\hline & 5 月 & 739 & $10 \%$ & 752 & $36 \%$ & 1564 & $54 \%$ \\
\hline & $6 \mathrm{~F}$ & 738 & 10 & 698 & $27 \%$ & 1769 & 72 \\
\hline & 7月 & 531 & $3 \%$ & 572 & $42 \%$ & 1364 & $55 \%$ \\
\hline & 8म & 607 & 4\% & 596 & 564 & 9811 & $40 \%$ \\
\hline & 9月 & 790 & $11 \%$ & 817 & $45 \%$ & 1492 & $44 \%$ \\
\hline & 10月 & 1091 & $18 \%$ & 1215 & 458 & 2201 & $36 \%$ \\
\hline & 11月 & 1718 & $24 \%$ & 1965 & $43 \%$ & 3812 & $33 \%$ \\
\hline & 12 & 2262 & $19 \%$ & 2782 & $42 \%$ & 5422 & $39 \%$ \\
\hline \multirow{12}{*}{ 那羁 } & 1月 & 1372 & $5 \%$ & 1529 & $41 \%$ & 2656 & $54 \%$ \\
\hline & $2 \xi$ & 1003 & 48 & 1108 & $37 \%$ & 2557 & $59 \%$ \\
\hline & 3月 & 700 & 28 & 816 & $40 \%$ & 2054 & $58 \%$ \\
\hline & 4月 & 697 & 38 & 675 & 328 & 1279 & 658 \\
\hline & $5 F$ & 617 & 44 & 599 & 347 & 1223 & 6830 \\
\hline & $6 \mathrm{~m}$ & 602 & 001 & 542 & $36 \%$ & 960 & $64 \%$ \\
\hline & $17=$ & 611 & 09 & 529 & $58 \%$ & 681 & 428 \\
\hline & 8月 & 541 & $2 \%$ & 545 & $71 \%$ & 774 & $27 \%$ \\
\hline & 9 月 & 575 & 38 & 631 & $69 \%$ & 1015 & $28 \%$ \\
\hline & 10 & 890 & $6 \%$ & 920 & $56 \%$ & 1450 & $38 \%$ \\
\hline & 11) & 1001 & $5 \%$ & 1187 & $53 \%$ & 1886 & $42 \%$ \\
\hline & 12月 & 1369 & $8 \%$ & 1540 & $47 \%$ & 3063 & $45 \%$ \\
\hline
\end{tabular}




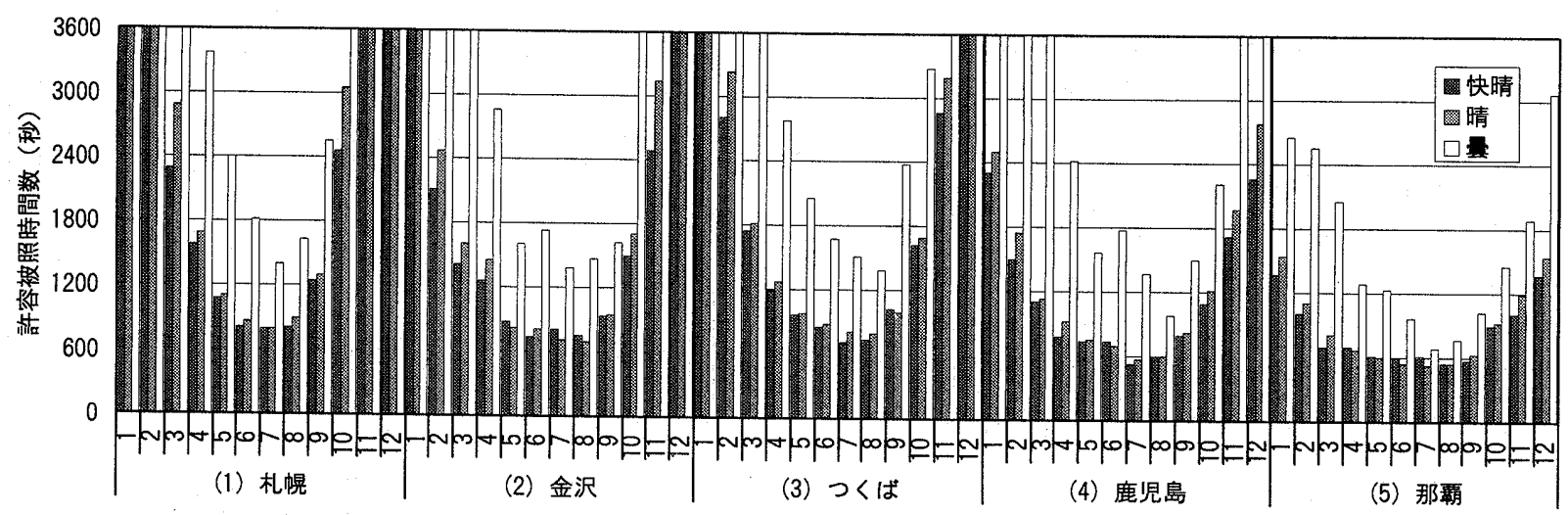

図 6 簡易天気分類に基づく許容被照時間数の地域別年変化（3600 秒までの範囲で表示）

（2）許容被照時間数の季節変化や, 時間数ランクに基づく出現頻度 分布の解析を通じて，地域ならびに季節による相違を把握した。ま た，許容被照時間数と日全天日射量との関係をクライモグラフ上に 表現し，その特性を検討した。

（3）簡易天気分類に基づく「快晴」「「晴」および「最」ごとに，許 容被照時間数を整理し，人体の紫外域日射被曝と天気との関係につ いて基礎的知見を得た。

今後は, 本研究で得られた成果が指し示すように, 正午前後の紫 外域日射データと各種気象データとの対応関係を詰めていくことが 必要と考えられる。

\section{付 記}

本研究の一部は, 平成 13 年度の文部省科学研究費・萌芽研究「生体影響柴 外線量 DUV の地域・天候・時間帯に基づく推定法開発と許容被照時間数の提 示（代表者：垂水弘夫)」によることを付記する。

\section{注 䣋}

1）カナダの SCI-TEC 社製。観測波長帯は $290 \sim 325 \mathrm{~nm}$ であり，0.5nm 刻みで 分光測定を実施。測定時間間隔は毎正時ごとの 1 時間。

2）「許容曝露時間」と表記される場合もあるが，ここでは太陽光に由来する 紫外域日射のみを対象とし，また受照面としても物ではなく人体を考えて いるので, 「許容被照時間」とした。

3）WHO（世界保健機関）が提示している基準許容被曝量 $30 \mathrm{~J} / \mathrm{m}^{2}$ (分光観 測值にアクションスペクトルによる波長帯域別の重み付けを行った DUV 值としての単位皮鹿表面積当たりエネルギー量）は，白色人種で紫外域日

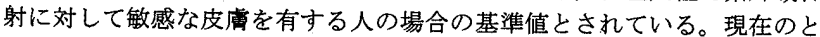
ころ日本人や黄色人種に関する基準許容被曝量は公表されていないので,
本研究では，この基準值を用いて解析を行った。なお，WHO で採用されて いる生体影響紫外線 DUV の算定方法等は既報 ${ }^{1)}$ に詳しいが, 分光観測を 行った各波長の UV 值に, 皮虚細胞中の DNA への波長別影響割合を考慮し た次式で示されるアクション・スペクトル（AS(L)，Lは波長）を乗じ，集 計することによって求められる。
AS (L) $=1-0.36\{(\mathrm{~L}-270) / 20\}^{1.64}$
AS (L) $=0.3 \times 0.7356^{(\mathrm{L}-300)}+10^{(2-0.0163 \mathrm{~L})}$
$290 \square \mathrm{L} \square 300 \mathrm{~nm}$ $300<\mathrm{L} \square 325 \mathrm{~nm}$

4）昼間の 9 時, 12 時, 15 時の平均雲量が, 1.5 未満を「快晴」, 1.5 以上 8.5 末満を「晴」， 8.5 以上を「罢」と区分している。

\section{文 献}

1）垂水弘夫，宮村壽，上出宣弘：紫外域日射分光観測に基づく生体影響紫外 域日射量 DUV の特性解析, 日本建築学会計画系論文集, 第 532 号, pp.73 $\sim 78,2000.6$

2）垂水弘夫, 上出亘弘：生体影響紫外域日射 DUV の雲量および簡易天気分 類に基づく解析, 日本建築学会計画系論文集, 第 545 号, pp.87 92, 2001.7

3) World Health Organization: Ultraviolet Radiation, Environmental Health Criteria 160, pp.231 234, 1994

4）気象庁 : オゾン層観測年報; $1991 \sim 2000$

5）気象庁：オゾン層観測報告, 1994 2000

6）気象庁 : 地上気象観測原簿データ, 気象業務支援センター

7）気象仢：気候変動監視レポート，1996〜2000

8) 気象庁: 気象年鑑, 大藏省印刷局, 2000

9）垂水弘夫，新聖子ほか：地上到達紫外線の DUV 評価と天気分類に基づく 解析, その 9 11, 日本建筑学会大会学術講演梗概集 D-1, pp.677 682, 2001.9

（2001年10月 9 日原稿受理， 2001 年 12 月 5 日採用決定 